OPEN ACCESS

Edited by: Christophe Matthys, KU Leuven, Belgium

Reviewed by: Melissa M. Markofski, University of Houston, United States Keith R. Martin University of Memphis, United States

*Correspondence: Ricardo Wesley Alberca ricardowesley@gmail.com

Specialty section: This article was submitted to

Nutritional Immunology, a section of the journal

Frontiers in Immunology

Received: 09 June 2020 Accepted: 07 September 2020 Published: 25 September 2020

Citation: Alberca RW, Teixeira FME, Beserra DR, de Oliveira EA, Andrade MMS, Pietrobon AJ and Sato MN (2020) Perspective: The Potential Effects of Naringenin in COVID-19.

Front. Immunol. 11:570919. doi: 10.3389/fimmu.2020.570919

\section{Perspective: The Potential Effects of Naringenin in COVID-19}

\author{
Ricardo Wesley Alberca ${ }^{1 *}$, Franciane Mouradian Emidio Teixeira ${ }^{2}$,

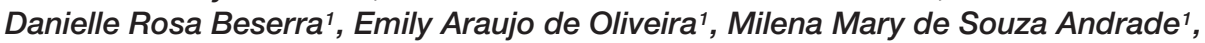 \\ Anna Julia Pietrobon ${ }^{2}$ and Maria Notomi Sato ${ }^{1}$
}

' Laboratory of Dermatology and Immunodeficiencies, LIM-56, Department of Dermatology, School of Medicine and Institute of Tropical Medicine of São Paulo, University of São Paulo, São Paulo, Brazil, ${ }^{2}$ Institute of Biomedical Sciences, University of São Paulo, São Paulo, Brazil

Coronavirus disease 2019 (COVID-19), caused by Severe Acute Respiratory Syndrome Coronavirus-2 (SARS-CoV-2), was declared a pandemic by the World Health Organization in March 2020. Severe COVID-19 cases develop severe acute respiratory syndrome, which can result in multiple organ failure, sepsis, and death. The higher risk group includes the elderly and subjects with pre-existing chronic illnesses such as obesity, hypertension, and diabetes. To date, no specific treatment or vaccine is available for COVID-19. Among many compounds, naringenin (NAR) a flavonoid present in citrus fruits has been investigated for antiviral and anti-inflammatory properties like reducing viral replication and cytokine production. In this perspective, we summarize NAR potential anti-inflammatory role in COVID-19 associated risk factors and SARSCoV-2 infection.

Keywords: antiviral, anti-inflammatory, naringenin, SARS-CoV-2, COVID-19, TNF, ACE2

\section{INTRODUCTION}

The respiratory diseases named Coronavirus disease 2019 (COVID-19) is generated by a respiratory infection with Severe Acute Respiratory Syndrome Coronavirus-2 (SARS-CoV-2) $(1,2)$. Due to the rapidl viral transmission, the disease was declared a pandemic by the World Health Organization a few months after the first diagnosed case $(3,4)$.

Besides the similar clinical manifestations to previous Severe Acute Respiratory Syndrome Coronavirus-1 (SARS-CoV-1), SARS-CoV-2 infection presents a much lower death rate (5). Approximately $5 \%$ of patients progress to a severe COVID-19, developing mainly severe acute respiratory syndrome, with $3 \%$ needing assisted respiratory mechanic ventilation. Coronavirus disease 2019 can progress to septic shock and multiple organ failure (6) and exhibits a death rate of approximately $2 \%(7)$.

The SARS-CoV-2 can infect human cells by entry via the angiotensin-converting enzyme 2 (ACE2) receptor and Transmembrane Serine Protease 2 (TMPRSS2) (8). Although this process is wildly accepted, other possible infective routes are being explored such as antibody-dependent enhancement (ADE) (7) and via CD147 (9).

Angiotensin-converting enzyme 2 expression is one of the main explanations for the higher airway infection, as it is highly expressed in the respiratory tract such as epithelial cells of the alveoli, trachea, and bronchi, some bronchial glands and alveolar macrophages (10). However, ACE2 is also expressed in the ileo, kidney, adipose tissue, heart, brain, blood vessels, stomach, liver, and oral and nasal mucosas (11), which could corroborate the systemic inflammatory profile in COVID-19. 
Upon viral entry, the virus induces the host to increase the production and release of inflammatory cytokines, which can lead to greater immune activation and tissue damage (12). Hypothetically, the reduction of inflammation could aid COVID19 patients (13).

Several compounds have been associated with antiviral and anti-inflammatory properties and could impact COVID-19 development such as vitamin D (14), vitamin E (15), vitamin B12 (16), omega-3 (17), and flavonoids (18). Naringenin (NAR) is an important natural flavonoid present in citrus fruits, like grapefruit $(43.5 \mathrm{mg} / 100 \mathrm{~mL})$ and oranges $(2.13 \mathrm{mg} / 100 \mathrm{~mL})$ (19), with a high analgesic, anti-oxidant, anti-inflammatory, anti-tumoral, and anti-viral effect (20-23) (Figure 1). The consumption of $8 \mathrm{~mL} / \mathrm{kg}$ of orange juice increases NAR plasma levels from 0 to $300 \mu \mathrm{g} / \mathrm{L} 4 \mathrm{~h}$ after ingestion (24).

The antiviral effect of NAR has been studied in several viruses, such as dengue $(25,26)$, hepatitis C (27), zika (28), chikungunya (29), Semliki Forest (30), herpes simplex 1 and 2 (31), yellow fever (32), and human immunodeficiency virus (33). Several in vitro studies have highlighted NAR's antiviral effect in pre-infection and post-infection (28). Similar to other natural compounds, NAR has extensively been investigated in in vitro, but has very limited results in in vivo models of viral infection $(34,35)$ (Figure 1B). Nevertheless, the in vitro and in vivo anti-inflammatory potential of NAR has been highlighted in several animal models, including respiratory syndromes $(35,36)$. In this perspective, we highlight the mechanism in which NAR may present an important anti-inflammatory role in COVID-19.

\section{ANTI-INFLAMMATORY PROPERTIES OF NARINGENIN}

Inflammation can be characterized by the regulation of proand anti-inflammatory mediators in resident cells and leukocytes recruited from the blood (37). There are strong pieces of evidence of the role of NAR under inflammatory conditions due to a wide range of mechanisms. The immunomodulatory properties of NAR are associated with the regulation of key signaling pathways, like nuclear factor kappa-light-chainenhancer of activated B cells (NF-KB) (38), PI3K/AKT (23), and mitogen-activated protein kinases (MAPK) (39) in different cell types (Figure 1A).

Macrophages are an important cell in the COVID-19 pathology, being able to sense and respond to pathogens and produce inflammatory cytokines and chemokines (40). In murine macrophages, NAR can reduce inflammatory mediators production induced by LPS, and in a murine endotoxemia model reduces the mortality rates from 60 to $0 \%$ (41). Murine macrophages infected with a gram-negative bacteria (Chlamydia trachomatis) NAR reduced the production of IL-1 $\beta$, IL1 $\alpha$, IL6, TNF, IL-12p70, and IL-10 in a dose-dependent manner (42). Moreover, NAR's anti-inflammatory effects have been demonstrated in vivo (41), in macrophage and ex vivo human whole-blood models, reducing IL-1 $\beta$, IL-6, IL-8, and TNF upon LPS stimulus to close to non-stimulated levels (43) (Figure 2).
Barnes et al. described that the cytokine storm developed by severe COVID-19 patients is related to an exacerbation of neutrophil activation (44). It is clear the central role of neutrophils in COVID-19, as neutrophilia and neutrophil-tolymphocyte ratio in COVID-19 patients is associated with disease severity $(45,46)$.

Lung biopsies have also identified an infiltration of neutrophils (47) and the formation of neutrophil extracellular traps in COVID-19 patients (48) (Figure 1A). Although some animals like cats, ferrets, mice, hamsters, and macaques can be infected by SARS-CoV-2, the usage of animal models in COVID-19 is currently limited (49).

In an animal model of acute respiratory distress syndrome (ARDS), a syndrome with an increase in IL-6, TNF, and neutrophils in the lungs, NAR supplementation can reduce neutrophils infiltration and oxidative stress, greatly reducing airway inflammation and lung injury (50). Naringenin reduction of oxidative stress is partially mediated by a curb in the anion superoxide production $(51,52)$ (Figure 2).

Naringenin can suppress inflammatory molecules production through both transcriptional and post-transcriptional mechanisms (18). In a LPS-induced model of inflammation in a mouse model, NAR suppressed TNF and IL-6 production by macrophages and $\mathrm{T}$ lymphocytes without interfering in the toll-like receptor (TLR) cascade but by increasing intracellular cytokine degradation through lysosome-dependent mechanisms (23). These data indicate a potential role in the control of inflammation and oxidative stress-related to airway inflammatory insults (Figure 2A). These anti-inflammatory and anti-oxidant effects are also described in chronic comorbidities like in diabetes mellitus $(53,54)$, dyslipidemia, hyperinsulinemia, and being overweight (55), which are all risk factors associated with severe COVID-19 $(4,56,57)$ (Figure 1C).

In animal experimental models, NAR was able to modulate different inflammation syndromes and at different sites, such as colitis (58), hepatitis (59), obesity (60), cancer (61), and acute respiratory syndrome (36). This is particularly important in COVID-19, because SARS-CoV-2 infection induces a systemic inflammation and can infect many different organs including lungs, heart, liver, brain, kidneys, and the intestines (62).

In addition, NAR can promote lysosome-dependent cytokine protein degradation, which may be important in COVID-19 (63, 64), considering the systemic and cytokine storm during severe COVID-19 (65). In fact, NAR-induced immunomodulation has been demonstrated in airway inflammatory disorders. In a murine asthma model, treatment with NAR reduced airway hyperactivity and airway inflammation, with a reduction in the levels of IL-4 and IL-13 in bronchoalveolar lavage and serum IgE levels as well improvement in lung function assay (66-68). Overall, the treatment with NAR reduced lung eosinophilia to similar levels to non-asthmatic group (66-68).

In lung fibrosis induced by infection with Mycoplasma pneumoniae, NAR reduced autophagy-mediated airway inflammation and lung fibrosis $(69,70)$, and, in a chronic obstructive pulmonary disease (COPD) model, NAR was able to mitigate lung inflammation, reduce the expression of TGF- $\beta$, and increase glucocorticoid receptor expression (GCR) 


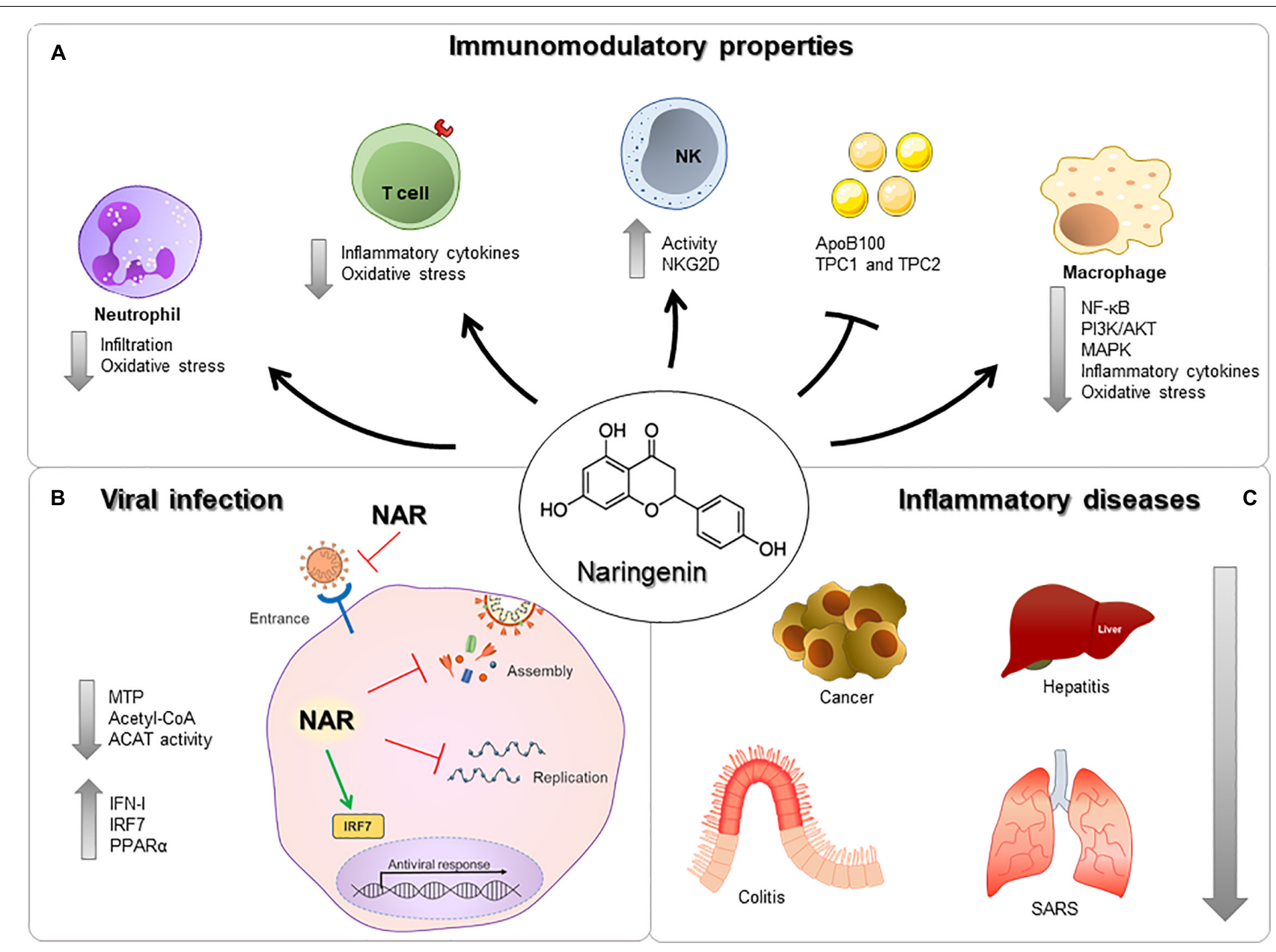

FIGURE 1 | Immunomodulatory properties of nargenin. (A) NAR can act on Neutrophils, T cells, NK cells, Macrophages, and reduce the expression of proteins and receptors. (B) NAR reduces viral entry, assembly, and replication via modulation of surface molecules, production of antiviral components, inflammatory molecules and/or direct interaction with viral components. (C) NAR can influence the development and severity of many different diseases, in different organs, such as cancer, hepatitis, colitis, and severe acute respiratory syndrome.

(71). Naringenin anti-inflammatory effect was also verified in radiation-induced lung injury, reducing lung inflammation and IL-1 $\beta$ levels (72).

The NAR anti-inflammatory effect is thus not directly mediated to a type 2 or type 1/17 immune response but a regulation of the immune response. Studies have highlighted the increase in T regulatory cells and transforming growth factor- $\beta$ after NAR consumption via aryl hydrocarbon receptor-mediated pathway (73).

Nevertheless, the excessive regulation of the inflammatory response could impair anti-viral immune response, that has not been previously observed with NAR supplementation. Naringenin can also activate the interferon-stimulated response element and enhance IFN-I production via an increase in the expression of IRF7 (74) and increase NK cell activity via enhanced NKG2D ligand expression (75). Considering the crucial role of NK cells and IFN-I in the anti-viral immune response, NAR may also contribute to the viral load control. Overall, these previous studies demonstrated, in vivo and in vitro, that NAR is a strong candidate as an adjuvant in reducing airway and systemic inflammation.

\section{NARINGENIN AND CORONAVIRUSES}

Two coronaviruses have been responsible for recent epidemics. In 2002, the SARS-CoV-1 epidemic caused 8,098 cases, with 774 deaths in 11 countries (76-78). In 2012, in the Middle East, another coronavirus also caused Severe Acute Respiratory Syndrome, being named MERS-CoV (79). Until 2020, MERSCoV had caused 2,494 cases, with 858 associated deaths (77).

Clinical manifestation of SARS-CoV-1 and MERS-CoV is similar. Patients report clinical symptoms such as fever, cough, body pain, headache, and less commonly, diarrhea and nausea (80). However, the need for intensive care and mechanical ventilation is greater in MERS-CoV than in SARS-CoV-1 $(81,82)$.

Similarly to MERS-CoV and SARS-CoV-1, SARS-CoV-2 infection is mainly transmitted by respiratory droplets expelled 


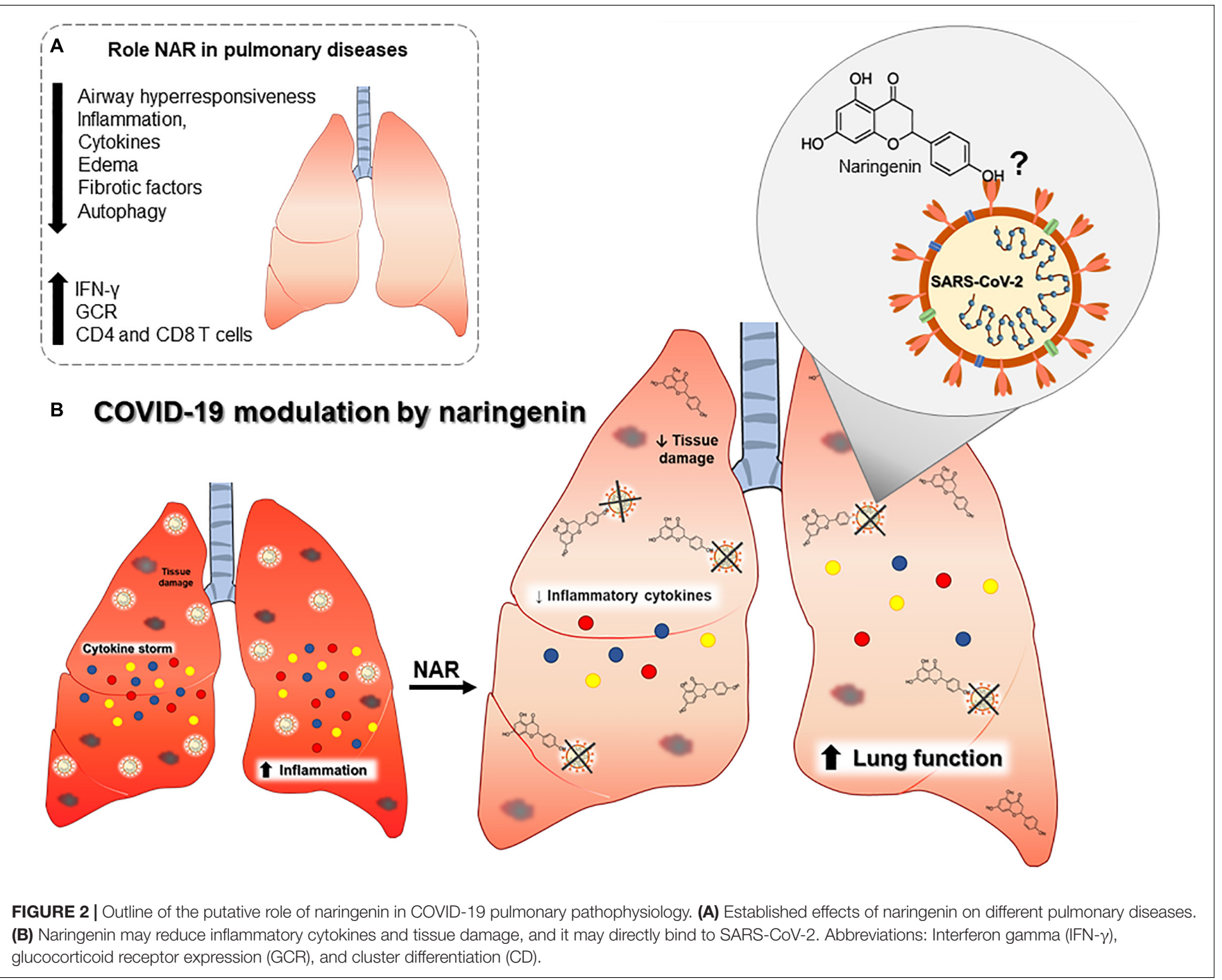

from an infected person during sneezes or coughs $(83,84)$. Severe Acute Respiratory Syndrome Coronavirus-2 surface glycoprotein spike (S protein) binds to ACE2 on the surface of the host's cell surface. This invading process is the same used by SARS-CoV1 (85). In comparison, MERS-CoV uses dipeptidyl peptidase 4 (DPP4), a multifunction surface protein to entry into cells (85). Dipeptidyl peptidase 4 is mainly expressed on the kidney, intestine, liver, prostate, and activated leukocytes. Dipeptidyl peptidase 4 is expressed on the lower respiratory tract, glands located in submucosa of the upper respiratory tract, lung macrophages, and alveolar epithelial cells (86).

After these coronaviruses (MERS-CoV, SARS-CoV-1, and SARS-CoV-2) invade the host's cell, polypeptides are released from the polyproteins by proteolytic processing. The proteolytic process is mediated by papain-like protease ( $\mathrm{PL}^{\mathrm{pro}}$ ) and 3chymotrypsin-like protease $\left(3 \mathrm{CL}^{\mathrm{pro}}\right)$. The $3 \mathrm{CL}^{\text {pro }}$ cleaves the polyprotein to generate various non-structural proteins, crucial for viral replication $(87,88)$. Due to the main role of $3 \mathrm{CL}$ in coronaviruses viral cycle, inhibitors of 3CL could potentially be used in COVID-19.
Flavonoid inhibition of the 3CL protease has been described in MERS-CoV (89) and SARS (90), but NAR was not among the flavonoids investigated. Nevertheless, in silico analysis demonstrated that NAR has the potential to inhibit SARS-CoV-2 $3 \mathrm{CL}^{\text {pro }}$ (91). A recent study verified that SARS-CoV-1 and SARSCoV-2 share $99.02 \%$ of genetic similarity of 3CL, with only 12 punctual mutations (88), leading to the possible inhibition of 3CL by NAR and other flavonoids.

Another possible mechanism is the inhibition of the twopore ionic channel (TPC1 and TPC2) (92). Inhibition of TPC1 and TPC2 reduces MERS-CoV infectivity, intracellular traffic (93), and viral replication $(93,94)$. Due to SARS-CoV-2 viral genome sequencing similarities with MERS-CoV and SARSCoV-1 (95), it is possible that similar mechanism of inhibition of TPC1 and TPC2 channel be effective in COVID-19, aiding in the reduction of viral replication (96).Interestingly, NAR can inhibit the activity of TPC1 and TPC2 both in humans and plants (97).

NAR is a hydrophilic substance with a higher affinity for the cytoplasmic membrane generating intracellular accumulation of 
NAR (98). Therefore, this affinity probably enhances intracellular signaling and the modulation of and TPC1 and TPC2 (27). Therefore, the TPC1 and TPC2's modulation by NAR should be further investigated as a possible anti-coronavirus intervention.

\section{DISCUSSION}

Several reports of natural compounds with anti-SARS-CoV-2 potential are currently being investigated. Substances that may compete with the ACE2 receptor or reduces the ACE2 expression may present an alternative or adjuvant therapy in COVID-19 (99). In fact, NAR consumption has been associated with a reduction in ACE2 expression in the kidneys of rats (100) and could bind directly to the ACE2 receptor (101).

However, nutritional interventions aiming to regulate SARSCoV-2 entry receptor ACE2 need to be carefully evaluated, as downregulating of ACE2 could also lead to greater inflammation and lung damage $(102,103)$. Previous reports demonstrated that the oral consumption of NAR can reduce acute lung injury in a mouse model (50) and reduce the production of proinflammatory cytokines (18). This is extremely relevant, as a part of COVID-19 lung injury can be classified as ARDS (104).

Coronavirus disease 2019 can also lead to cytokine storm, progress to septic shock, and cause death $(105,106)$. Modulating the cytokine storm is thus a vital process for treating COVID-19. Naringenin has been used in experimental models to regulate the production of IL- 6 and TNF (23), cytokines that are increased in COVID-19 and further increased in severe cases $(107,108)$. Also in an animal model of septic shock, the consumption of NAR has been demonstrated to reduce kidney damage via an increase in antioxidant enzymes (109).

Studies verified a direct role of NAR in abrogating viral replication in human cells, before (21) and after infection (30). In SARS-CoV2, in silico analysis demonstrated that NAR has the potential to inhibit SARS-CoV-2 $3 \mathrm{CL}^{\text {pro }}$ and consequently inhibit viral replication (91), which still needs to be further verified experimentally.

The consumption of NAR via citrus fruits (110) or supplementation (111) can rapidly increase circulating levels of NAR and increase intracellular levels of NAR $(98,111)$. An increase in the concentration of NAR in plasma samples can be observed $20 \mathrm{~min}$ oral consumption and peaking around $4 \mathrm{~h}$ post-consumption (112). In addition, in vitro models have also demonstrated a long-term anti-viral benefit, even after discontinuation of supplementation with NAR (21), although there is little evidence of in vivo antiviral activity (35).

Previous clinical trials with the consumption of $500 \mathrm{~mL} /$ day for 8 weeks of orange juice, rich in NAR, has demonstrated an adjuvant effect in antiviral therapy (34). The consumption of

\section{REFERENCES}

1. Alberca GGF, Fernandes IG, Sato MN, Alberca RW. What is COVID-19? Front Young Minds. (2020) 8:74. doi: 10.3389/frym.2020. 00074
$340 \mathrm{~mL}$ of grapefruit juice per day (containing approximately $210 \mathrm{mg}$ of NAR) also improved cardiac-related measurements in post-menopause women (113). Although NAR is one of the most important naturaly occurring flavonoids, there is a lack of clinical trials and data on pharmacokinetic aspects, metabolic fate, and chemical stability that may limit the usage of this bioactive compound in humans (35).

A caveat of NAR is the oral consumption. Although widely accepted by patients, it could be a barrier in severe COVID19 patients. Therefore, NAR may be better applied as a prophylactic intervention or on the onset of SARS-CoV-2 infection. The possible effect of NAR on the ACE2 receptor also needs to investigated, as ACE2 reduction could lead to greater inflammation $(102,103)$. Naringenin is mostly absorbed in the small intestine (114), and differences in microbiota may thus also present an important inter-individual variable $(24,112)$.

Another caveat is the NAR poor aqueous solubility and bioavailability; currently, the usage of liposomes, nanoparticles, and other formulations may present itself as a solution (115-118).

Furthermore, NAR interactions with the cytochrome P450 (CYP) system need to be evaluated, as NAR can affect drugmetabolizing enzymes and pharmacokinetic of important drugs that may be of regular use or specific in COVID-19 patients (119-121).

In conclusion, NAR potential as an anti-inflammatory nutritional intervention has been demonstrated in many different diseases, such as SARS-CoV-1 and MERS-CoV. Further investigations and clinical trials are needed to help understand the role of NAR consumption in humans during a viral infection, especially in SARS-CoV-2 infection and COVID-19.

\section{DATA AVAILABILITY STATEMENT}

All datasets generated in this study are included in the article/supplementary material.

\section{AUTHOR CONTRIBUTIONS}

RA: conception, writing, and review. FT: writing, drawing, and review. DB, EO, MA, AP, and MS: writing and review. All authors contributed to the article and approved the submitted version.

\section{FUNDING}

RA holds a post-doctorate fellowship from FAPESP (19/02679-7). FT holds a doctorate fellowship from FAPESP (18/18230-6). EO holds a scientific initiation fellowship from FAPESP (19/269286). MS have a research grant from FAPESP (17/18199-9).

2. Cao X. COVID-19: immunopathology and its implications for therapy. Nat Rev Immunol. (2020) 20:269-70. doi: 10.1038/s41577-020-0308-3

3. South AM, Diz DI, Chappell MC. COVID-19, ACE2, and the cardiovascular consequences. Am J Physiol Heart Circ Physiol. (2020) 318:H1084-90. doi: 10.1152/ajpheart.00217.2020 
4. Chen H, Guo J, Wang C, Luo F, Yu X, Zhang W, et al. Clinical characteristics and intrauterine vertical transmission potential of COVID-19 infection in nine pregnant women: a retrospective review of medical records. Lancet. (2020) 395:809-15. doi: 10.1016/S0140-6736(20)30360-3

5. Wu Z, McGoogan JM. Characteristics of and important lessons from the Coronavirus disease 2019 (COVID-19) outbreak in China. JAMA. (2020) 323:1239-42. doi: 10.1001/jama.2020.2648

6. Xie M, Chen Q. Insight into 2019 novel coronavirus - an updated interim review and lessons from SARS-CoV and MERS-CoV. Int J Infect Dis. (2020) 94:119-24. doi: 10.1016/j.ijid.2020.03.071

7. Peron JPS, Nakaya H, Peron JPS, Nakaya H. Susceptibility of the elderly to SARS-CoV-2 infection: ACE-2 overexpression, shedding, and antibodydependent enhancement (ADE). Clinics. (2020) 75:e1912. doi: 10.6061/ clinics/2020/e1912

8. Palmeira P, Barbuto JAM, Silva CAA, Carneiro-Sampaio M, Palmeira P, Barbuto JAM, et al. Why is SARS-CoV-2 infection milder among children? Clinics. (2020) 75:e1947. doi: 10.6061/clinics/2020/e1947

9. Wang K, Chen W, Zhou Y-S, Lian J-Q, Zhang Z, Du P, et al. SARS-CoV-2 invades host cells via a novel route: $\mathrm{CD} 147$-spike protein. bioRxiv[Preprint]. (2020):doi: 10.1101/2020.03.14.988345

10. Yin Y, Wunderink RG. MERS, SARS and other coronaviruses as causes of pneumonia. Respirology. (2018) 23:130-7. doi: 10.1111/resp.13196

11. Gembardt F, Sterner-Kock A, Imboden H, Spalteholz M, Reibitz F, Schultheiss HP, et al. Organ-specific distribution of ACE2 mRNA and correlating peptidase activity in rodents. Peptides. (2005) 26:1270-7. doi: 10.1016/j. peptides.2005.01.009

12. Conti P, Ronconi G, Caraffa A, Gallenga CE, Ross R, Frydas I, et al. Induction of pro-inflammatory cytokines (IL-1 and IL-6) and lung inflammation by COVID-19: anti-inflammatory strategies. J Biol Regul Homeost Agents. (2020) 34:327-31. doi: 10.23812/CONTI-E

13. Letko M, Marzi A, Munster V. Functional assessment of cell entry and receptor usage for SARS-CoV-2 and other lineage B betacoronaviruses. Nat Microbiol. (2020) 5:562-9. doi: 10.1038/s41564-020-0688-y

14. Hansdottir S, Monick MM, Lovan N, Powers L, Gerke A, Hunninghake GW. Vitamin D decreases respiratory syncytial virus induction of NF- $\mathrm{kB}-$ linked chemokines and cytokines in airway epithelium while maintaining the antiviral state. J Immunol. (2010) 184:965-74. doi: 10.4049/jimmunol. 0902840

15. Andreone P, Fiorino S, Cursaro C, Gramenzi A, Margotti M, Di Giammarino L, et al. Vitamin E as treatment for chronic hepatitis B: results of a randomized controlled pilot trial. Antiviral Res. (2001) 49:75-81. doi: 10. 1016/S0166-3542(00)00141-8

16. Tamura J, Kubota K, Murakami H, Sawamura M, Matsushima T, Tamura $\mathrm{T}$, et al. Immunomodulation by vitamin B12: augmentation of CD8+ T lymphocytes and natural killer (NK) cell activity in vitamin B12-deficient patients by methyl-B12 treatment. Clin Exp Immunol. (1999) 116:28-32. doi: 10.1046/j.1365-2249.1999.00870.x

17. Braz-De-Melo HA, Pasquarelli-do-Nascimento G, Corrêa R, das Neves Almeida R, de Oliveira Santos I, Prado PS, et al. Potential neuroprotective and anti-inflammatory effects provided by omega-3 (DHA) against Zika virus infection in human SH-SY5Y cells. Sci Rep. (2019) 9:20119. doi: 10.1038/ s41598-019-56556-y

18. Gupta SC, Tyagi AK, Deshmukh-Taskar P, Hinojosa M, Prasad S, Aggarwal BB. Downregulation of tumor necrosis factor and other proinflammatory biomarkers by polyphenols. Arch Biochem Biophys. (2014) 559:91-9. doi: 10.1016/j.abb.2014.06.006

19. Hartogh DJD, Tsiani E. Antidiabetic properties of naringenin: a citrus fruit Polyphenol. Biomolecules. (2019) 9:99. doi: 10.3390/biom903 0099

20. Pinho-Ribeiro FA, Zarpelon AC, Fattori V, Manchope MF, Mizokami SS, Casagrande R, et al. Naringenin reduces inflammatory pain in mice. Neuropharmacology. (2016) 105:508-19. doi: 10.1016/j.neuropharm.2016. 02.019

21. Goldwasser J, Cohen PY, Lin W, Kitsberg D, Balaguer P, Polyak SJ, et al. Naringenin inhibits the assembly and long-term production of infectious hepatitis $\mathrm{C}$ virus particles through a PPAR-mediated mechanism. J Hepatol. (2011) 55:963-71. doi: 10.1016/j.jhep.2011.02.011
22. Zhang FY, Du GJ, Zhang L, Zhang CL, Lu WL, Liang W. Naringenin enhances the anti-tumor effect of doxorubicin through selectively inhibiting the activity of multidrug resistance-associated proteins but not P-glycoprotein. Pharm Res. (2009) 26:914-25. doi: 10.1007/s11095-008-9793-y

23. Jin L, Zeng W, Zhang F, Zhang C, Liang W. Naringenin ameliorates acute inflammation by regulating intracellular cytokine degradation. J Immunol. (2017) 199:3466-77. doi: 10.4049/jimmunol.1602016

24. Erlund I, Meririnne E, Alfthan G, Aro A. Plasma kinetics and urinary excretion of the flavanones naringenin and hesperetin in humans after ingestion of orange juice and grapefruit juice. J Nutr. (2001) 131:235-41. doi: 10.1093/jn/131.2.235

25. Zandi K, Teoh BT, Sam SS, Wong PF, Mustafa MR, Abubakar S. In vitro antiviral activity of Fisetin, Rutin and Naringenin against Dengue virus type-2. J Med Plant Res. (2011) 5:5534-9.

26. Frabasile S, Koishi AC, Kuczera D, Silveira GF, Verri WA, Dos Santos CND, et al. The citrus flavanone naringenin impairs dengue virus replication in human cells. Sci Rep. (2017) 7:41864. doi: 10.1038/srep41864

27. Nahmias Y, Goldwasser J, Casali M, Van Poll D, Wakita T, Chung RT, et al. Apolipoprotein B-dependent hepatitis C virus secretion is inhibited by the grapefruit flavonoid naringenin. Hepatology. (2008) 47:1437-45. doi: 10.1002/hep. 22197

28. Cataneo AHD, Kuczera D, Koishi AC, Zanluca C, Silveira GF, de Arruda TB, et al. The citrus flavonoid naringenin impairs the in vitro infection of human cells by Zika virus. Sci Rep. (2019) 9:16348. doi: 10.1038/s41598-019-52626-3

29. Ahmadi A, Hassandarvish P, Lani R, Yadollahi P, Jokar A, Bakar SA, et al. Inhibition of chikungunya virus replication by hesperetin and naringenin. RSC Adv. (2016) 6:69421-30. doi: 10.1039/c6ra16640g

30. Pohjala L, Utt A, Varjak M, Lulla A, Merits A, Ahola T, et al. Inhibitors of alphavirus entry and replication identified with a stable Chikungunya replicon cell line and virus-based assays. PLoS One. (2011) 6:e28923. doi: 10.1371/journal.pone.0028923

31. Lyu SY, Rhim JY, Park WB. Antiherpetic activities of flavonoids against herpes simplex virus type 1 (HSV-1) and type 2 (HSV-2) in vitro. Arch Pharm Res. (2005) 28:1293-301. doi: 10.1007/BF02978215

32. Castrillo M, Córdova T, Cabrera G, Rodríguez-Ortega M. Effect of naringenin, hesperetin and their glycosides forms on the replication of the 17D strain of yellow fever virus (Efecto de la naringenina, hesperetina y sus formas glicosidadas sobre la replicación de la cepa 17D del virus de la fiebre amarilla). Av en Biomed. (2015) 4:69-78.

33. da Silva CCF, Salatino A, Motta LB da, Negri G, Salatino MLF. Chemical characterization, antioxidant and anti-HIV activities of a Brazilian propolis from Ceará state. Braz J Pharmacogn. (2019) 29:309-18. doi: 10.1016/j.bjp. 2019.04.001

34. Gonçalves D, Lima C, Ferreira P, Costa P, Costa A, Figueiredo W, et al. Orange juice as dietary source of antioxidants for patients with hepatitis $\mathrm{C}$ under antiviral therapy. Food Nutr Res. (2017) 61:1296675. doi: 10.1080/16546628. 2017.1296675

35. Salehi B, Fokou PVT, Sharifi-Rad M, Zucca P, Pezzani R, Martins N, et al. The therapeutic potential of naringenin: a review of clinical trials. Pharmaceuticals. (2019) 12:11. doi: 10.3390/ph12010011

36. Fouad AA, Albuali WH, Jresat I. Protective effect of naringenin against lipopolysaccharide-induced acute lung injury in rats. Pharmacology. (2016) 97:224-32. doi: 10.1159/000444262

37. Lawrence $\mathrm{T}$. The nuclear factor NF-kappaB pathway in inflammation. Cold Spring Harb Perspect Biol. (2009) 1:a001651. doi: 10.1101/cshperspect. a001651

38. Pinho-Ribeiro FA, Zarpelon AC, Mizokami SS, Borghi SM, Bordignon J, Silva RL, et al. The citrus flavonone naringenin reduces lipopolysaccharideinduced inflammatory pain and leukocyte recruitment by inhibiting NFкB activation. J Nutr Biochem. (2016) 33:8-14. doi: 10.1016/j.jnutbio.2016. 03.013

39. Chen S, Ding Y, Tao W, Zhang W, Liang T, Liu C. Naringenin inhibits TNF$\alpha$ induced VSMC proliferation and migration via induction of HO-1. Food Chem Toxicol. (2012) 50:3025-31. doi: 10.1016/j.fct.2012.06.006

40. Merad M, Martin JC. Pathological inflammation in patients with COVID19: a key role for monocytes and macrophages. Nat Rev Immunol. (2020) 20:355-62. doi: 10.1038/s41577-020-0331-4 
41. Liu X, Wang N, Fan S, Zheng X, Yang Y, Zhu Y, et al. The citrus flavonoid naringenin confers protection in a murine endotoxaemia model through AMPK-ATF3-dependent negative regulation of the TLR4 signalling pathway. Sci Rep. (2016) 6:39735. doi: 10.1038/srep39735

42. Yilma AN, Singh SR, Morici L, Dennis VA. Flavonoid naringenin: a potential immunomodulator for Chlamydia trachomatis inflammation. Mediators Inflamm. (2013) 2013:102457. doi: 10.1155/2013/102457

43. Bodet C, La VD, Epifano F, Grenier D. Naringenin has anti-inflammatory properties in macrophage and ex vivo human whole-blood models. $J$ Periodontal Res. (2008) 43:400-7. doi: 10.1111/j.1600-0765.2007.01055.x

44. Barnes BJ, Adrover JM, Baxter-Stoltzfus A, Borczuk A, Cools-Lartigue J, Crawford JM, et al. Targeting potential drivers of COVID-19: neutrophil extracellular traps. J Exp Med. (2020) 217:e20200652. doi: 10.1084/jem. 20200652

45. Wang D, Hu B, Hu C, Zhu F, Liu X, Zhang J, et al. Clinical characteristics of 138 hospitalized patients with 2019 Novel Coronavirus-infected Pneumonia in Wuhan, China. JAMA. (2020) 323:1061-9. doi: 10.1001/jama.2020.1585

46. Liu J, Liu Y, Xiang P, Pu L, Xiong H, Li C, et al. Neutrophil-to-lymphocyte ratio predicts severe illness patients with 2019 Novel Coronavirus in the early stage. medRxiv[Preprint]. (2020):doi: 10.1101/2020.02.10.20021584

47. Yao XH, Li TY, He ZC, Ping YF, Liu HW, Yu SC, et al. [A pathological report of three COVID-19 cases by minimally invasive autopsies]. Zhonghua bing li xue za zhi. (2020) 49:411-7. doi: 10.3760/cma.j.cn112151-2020031200193

48. Fox SE, Akmatbekov A, Harbert JL, Li G, Brown JQ, Heide RS, et al. Pulmonary and cardiac pathology in Covid-19: the first autopsy series from New Orleans. medRxiv[Preprint]. (2020) doi: 10.1101/2020.04.06.2005 0575

49. Shi J, Wen Z, Zhong G, Yang H, Wang C, Huang B, et al. Susceptibility of ferrets, cats, dogs, and other domesticated animals to SARS-coronavirus 2. Science. (2020) 368:1016-20. doi: 10.1126/science.abb7015

50. Zhao M, Li C, Shen F, Wang M, Jia N, Wang C. Naringenin ameliorates LPSinduced acute lung injury through its anti-oxidative and anti-inflammatory activity and by inhibition of the PI3K/AKT pathway. Exp Ther Med. (2017) 14:2228-34. doi: 10.3892/etm.2017.4772

51. Manchope MF, Calixto-Campos C, Coelho-Silva L, Zarpelon AC, PinhoRibeiro FA, Georgetti SR, et al. Naringenin inhibits superoxide anioninduced inflammatory pain: role of oxidative stress, cytokines, Nrf-2 and the no-cGMP-PKG-KATP channel signaling pathway. PLoS One. (2016) 11:e0153015. doi: 10.1371/journal.pone.0153015

52. Martinez RM, Pinho-Ribeiro FA, Steffen VS, Caviglione CV, Vignoli JA, Barbosa DS, et al. Naringenin inhibits UVB irradiation-induced inflammation and oxidative stress in the skin of hairless mice. J Nat Prod. (2015) 78:1647-55. doi: 10.1021/acs.jnatprod.5b00198

53. Nguyen-Ngo C, Willcox JC, Lappas M. Anti-diabetic, anti-inflammatory, and anti-oxidant effects of naringenin in an in vitro human model and an in vivo murine model of gestational diabetes mellitus. Mol Nutr Food Res. (2019) 63:e1900224. doi: 10.1002/mnfr.201900224

54. Al-Rejaie SS, Aleisa AM, Abuohashish HM, Parmar MY, Ola MS, Al-Hosaini AA, et al. Naringenin neutralises oxidative stress and nerve growth factor discrepancy in experimental diabetic neuropathy. Neurol Res. (2015) 37:92433. doi: 10.1179/1743132815Y.0000000079

55. Mulvihill EE, Allister EM, Sutherland BG, Telford DE, Sawyez CG, Edwards JY, et al. Naringenin prevents dyslipidemia, apolipoprotein B overproduction, and hyperinsulinemia in LDL receptor-null mice with diet-induced insulin resistance. Diabetes. (2009) 58:2198-210. doi: 10.2337/db09-0634

56. Wu C, Chen X, Cai Y, Xia J, Zhou X, Xu S, et al. Risk factors associated with acute respiratory distress syndrome and death in patients with Coronavirus disease 2019 Pneumonia in Wuhan, China. JAMA Intern Med. (2020) 180:934-43. doi: 10.1001/jamainternmed.2020.0994

57. Alberca RW, Oliveira LM, Branco ACCC, Pereira NZ, Sato MN. Obesity as a risk factor for COVID-19: an overview. Crit Rev Food Sci Nutr. (2020):doi: 10.1080/10408398.2020.1775546 [Epub ahead of print],

58. Dou W, Zhang J, Sun A, Zhang E, Ding L, Mukherjee S, et al. Protective effect of naringenin against experimental colitis via suppression of Toll-like receptor 4/NF-KB signalling. Br J Nutr. (2013) 110:599-608. doi: 10.1017/ S0007114512005594
59. Jain A, Yadav A, Bozhkov AI, Padalko VI, Flora SJS. Therapeutic efficacy of silymarin and naringenin in reducing arsenic-induced hepatic damage in young rats. Ecotoxicol Environ Saf. (2011) 74:607-14. doi: 10.1016/j.ecoenv. 2010.08.002

60. Assini JM, Mulvihill EE, Burke AC, Sutherland BG, Telford DE, Chhoker SS, et al. Naringenin prevents obesity, hepatic steatosis, and glucose intolerance in male mice independent of fibroblast growth factor 21. Endocrinology. (2015) 156:2087-92. doi: 10.1210/en.2014-2003

61. Qin L, Jin L, Lu L, Lu X, Zhang C, Zhang F, et al. Naringenin reduces lung metastasis in a breast cancer resection model. Protein Cell. (2011) 2:507-16. doi: 10.1007/s13238-011-1056-8

62. Zhang Y, Geng X, Tan Y, Li Q, Xu C, Xu J, et al. New understanding of the damage of SARS-CoV-2 infection outside the respiratory system. Biomed Pharmacother. (2020) 127:110195. doi: 10.1016/j.biopha.2020.11 0195

63. Smith AM, Rahman FZ, Hayee B, Graham SJ, Marks DJB, Sewell GW, et al. Disordered macrophage cytokine secretion underlies impaired acute inflammation and bacterial clearance in Crohn's disease. J Exp Med. (2009) 206:1883-97. doi: 10.1084/jem.20091233

64. Zeng W, Jin L, Zhang F, Zhang C, Liang W. Naringenin as a potential immunomodulator in therapeutics. Pharmacol Res. (2018) 135:122-6. doi: 10.1016/j.phrs.2018.08.002

65. Jose RJ, Manuel A. COVID-19 cytokine storm: the interplay between inflammation and coagulation. Lancet Respir Med. (2020) 8:e46-7. doi: 10. 1016/S2213-2600(20)30216-2

66. Iwamura C, Shinoda K, Yoshimura M, Watanabe Y, Obata A, Nakayama T. Naringenin chalcone suppresses allergic asthma by inhibiting the type-2 function of CD4 T cells. Allergol Int. (2010) 59:67-73. doi: 10.2332/allergolint. 09-OA-0118

67. Guihua X, Shuyin L, Jinliang G, Wang S. Naringin protects ovalbumininduced airway inflammation in a mouse model of Asthma. Inflammation. (2016) 39:891-9. doi: 10.1007/s10753-016-0321-7

68. Shi Y, Dai J, Liu H, Li RR, Sun PL, Du Q, et al. Naringenin inhibits allergeninduced airway inflammation and airway responsiveness and inhibits NF- $\kappa \mathrm{B}$ activity in a murine model of asthma. Can J Physiol Pharmacol. (2009) 87:729-35. doi: 10.1139/Y09-065

69. Du G, Jin L, Han X, Song Z, Zhang H, Liang W. Naringenin: a potential immunomodulator for inhibiting lung fibrosis and metastasis. Cancer Res. (2009) 69:3205-12. doi: 10.1158/0008-5472.CAN-08-3393

70. Lin Y, Tan D, Kan Q, Xiao Z, Jiang Z. The protective effect of naringenin on airway remodeling after mycoplasma pneumoniae infection by inhibiting autophagymediated lung inflammation and fibrosis. Mediators Inflamm. (2018) 2018:8753894. doi: 10.1155/2018/8753894

71. Liu J, Yao J, Zhang J. Naringenin attenuates inflammation in chronic obstructive pulmonary disease in cigarette smoke induced mouse model and involves suppression of NF-кB. J Microbiol Biotechnol. (2018):doi: 10.4014/ jmb.1810.10061 [Epub ahead of print],

72. Zhang C, Zeng W, Yao Y, Xu B, Wei X, Wang L, et al. Naringenin ameliorates radiation-induced lung injury by lowering IL-1b levels. J Pharmacol Exp Ther. (2018) 366:341-8. doi: 10.1124/jpet.118.248807

73. Wang HK, Yeh CH, Iwamoto T, Satsu H, Shimizu M, Totsuka M. Dietary flavonoid naringenin induces regulatory $\mathrm{T}$ cells via an aryl hydrocarbon receptor mediated pathway. J Agric Food Chem. (2012) 60:2171-8. doi: 10. 1021/jf204625y

74. Fast DJ, Stern NP, Chuang J, Li Y, Scholten JD, Hu C. Flavanones common to citrus fruits activate the interferon-stimulated response element by stimulating expression of IRF7. J Food Bioact. (2019) 8:58-65. doi: 10.31665/ jfb.2019.8207

75. Kim JH, Lee JK. Naringenin enhances NK cell lysis activity by increasing the expression of NKG2D ligands on Burkitt's lymphoma cells. Arch Pharm Res. (2015) 38:2042-8. doi: 10.1007/s12272-015-0624-5

76. Kuba K, Imai Y, Rao S, Gao H, Guo F, Guan B, et al. A crucial role of angiotensin converting enzyme 2 (ACE2) in SARS coronavirus-induced lung injury. Nat Med. (2005) 11:875-9. doi: 10.1038/nm1267

77. Mahase E. Coronavirus covid-19 has killed more people than SARS and MERS combined, despite lower case fatality rate. BMJ. (2020) 368:m641. doi: 10.1136/bmj.m641 
78. Weiss SR, Leibowitz JL. Coronavirus pathogenesis. In: Maramorosch K, Shatkin AJ, Murphy FA editors. Advances in Virus Research. (Vol. 81), Cambridge, MA: Academic Press Inc (2011). p. 85-164. doi: 10.1016/B9780-12-385885-6.00009-2

79. Chan JFW, Lau SKP, To KKW, Cheng VCC, Woo PCY, Yue KY. Middle east respiratory syndrome coronavirus: another zoonotic betacoronavirus causing SARS-like disease. Clin Microbiol Rev. (2015) 28:465-522. doi: 10.1128/CMR. 00102-14

80. De Wit E, Van Doremalen N, Falzarano D, Munster VJ. SARS and MERS: recent insights into emerging coronaviruses. Nat Rev Microbiol. (2016) 14:523-34. doi: 10.1038/nrmicro.2016.81

81. Saad M, Omrani AS, Baig K, Bahloul A, Elzein F, Matin MA, et al. Clinical aspects and outcomes of 70 patients with Middle East respiratory syndrome coronavirus infection: a single-center experience in Saudi Arabia. Int J Infect Dis. (2014) 29:301-6. doi: 10.1016/j.ijid.2014.09.003

82. Peiris JSM, Chu CM, Cheng VCC, Chan KS, Hung IFN, Poon LLM, et al. Clinical progression and viral load in a community outbreak of coronavirusassociated SARS pneumonia: a prospective study. Lancet. (2003) 361:176772. doi: 10.1016/S0140-6736(03)13412-5

83. Rabaan AA, Al-Ahmed SH, Haque S, Sah R, Tiwari R, Malik YS, et al. SARSCoV-2, SARS-CoV, and MERS-COV: a comparative overview. Le Infez Med. (2020) 28:174-84

84. Rockx B, Kuiken T, Herfst S, Bestebroer T, Lamers MM, Oude Munnink $\mathrm{BB}$, et al. Comparative pathogenesis of COVID-19, MERS, and SARS in a nonhuman primate model. Science. (2020) 368:1012-5. doi: 10.1126/science. abb7314

85. Wu A, Peng Y, Huang B, Ding X, Wang X, Niu P, et al. Genome composition and divergence of the novel Coronavirus (2019-nCoV) originating in China. Cell Host Microbe. (2020) 27:325-8. doi: 10.1016/j.chom.2020. 02.001

86. Widagdo W, Raj VS, Schipper D, Kolijn K, van Leenders GJLH, Bosch $\mathrm{BJ}$, et al. Differential expression of the middle east respiratory syndrome coronavirus receptor in the upper respiratory tracts of humans and dromedary camels. J Virol. (2016) 90:4838-42. doi: 10.1128/jvi.02994-15

87. Anand K, Ziebuhr J, Wadhwani P, Mesters JR, Hilgenfeld R. Coronavirus main proteinase (3CLpro) structure: basis for design of anti-SARS drugs. Science. (2003) 300:1763-7. doi: 10.1126/science.1085658

88. ul Qamar MT, Alqahtani SM, Alamri MA, Chen L-L. Structural basis of SARS-CoV-2 3CLpro and anti-COVID-19 drug discovery from medicinal plants. J Pharm Anal. (2020) 10:313-9. doi: 10.1016/j.jpha.2020.03.009

89. Jo S, Kim H, Kim S, Shin DH, Kim MS. Characteristics of flavonoids as potent MERS-CoV 3C-like protease inhibitors. Chem Biol Drug Des. (2019) 94:2023-30. doi: 10.1111/cbdd.13604

90. Jo S, Kim S, Shin DH, Kim MS. Inhibition of SARS-CoV 3CL protease by flavonoids. J Enzyme Inhib Med Chem. (2020) 35:145-51. doi: 10.1080/ 14756366.2019.1690480

91. Khaerunnisa S, Kurniawan H, Awaluddin R, Suhartati S. Potential inhibitor of COVID-19 main protease (M pro) from several medicinal plant compounds by molecular docking study. Preprints. (2020):doi: 10.20944/ preprints202003.0226.v1

92. Shen $\mathrm{D}$, Wang $\mathrm{X}, \mathrm{Xu} \mathrm{H}$. Pairing phosphoinositides with calcium ions in endolysosomal dynamics: phosphoinositides control the direction and specificity of membrane trafficking by regulating the activity of calcium channels in the endolysosomes. BioEssays. (2011) 33:448-57. doi: 10.1002/ bies. 201000152

93. Gunaratne GS, Yang Y, Li F, Walseth TF, Marchant JS. NAADP-dependent $\mathrm{Ca} 2+$ signaling regulates Middle East respiratory syndrome-coronavirus pseudovirus translocation through the endolysosomal system. Cell Calcium. (2018) 75:30-41. doi: 10.1016/j.ceca.2018.08.003

94. Burkard C, Verheije MH, Wicht O, van Kasteren SI, van Kuppeveld FJ, Haagmans BL, et al. coronavirus cell entry occurs through the Endo/Lysosomal pathway in a proteolysis-dependent manner. PLoS Pathog. (2014) 10:e1004502. doi: 10.1371/journal.ppat.1004502

95. Grimm C, Tang R. Could an endo-lysosomal ion channel be the Achilles heel of SARS-CoV2? Cell Calcium. (2020) 88:102212. doi: 10.1016/j.ceca.2020. 102212
96. Tay MZ, Poh CM, Rénia L, MacAry PA, Ng LFP. The trinity of COVID19: immunity, inflammation and intervention. Nat Rev Immunol. (2020) 20:363-74. doi: 10.1038/s41577-020-0311-8

97. Benkerrou D, Minicozzi V, Gradogna A, Milenkovic S, Bodrenko IV, Festa M, et al. A perspective on the modulation of plant and animal two pore channels (TPCs) by the flavonoid naringenin. Biophys Chem. (2019) 254:106246. doi: $10.1016 / j . b p c .2019 .106246$

98. Recourt K, van Brussel AA, Driessen AJ, Lugtenberg BJ. Accumulation of a nod gene inducer, the flavonoid naringenin, in the cytoplasmic membrane of Rhizobium leguminosarum biovar viciae is caused by the $\mathrm{pH}$-dependent hydrophobicity of naringenin. J Bacteriol. (1989) 171:4370-7. doi: 10.1128/ jb.171.8.4370-4377.1989

99. Chen H, Du Q. Potential natural compounds for preventing SARS-CoV2 (2019-nCoV) infection. Preprints. (2020):doi: 10.20944/preprints202001. 0358.v3

100. Wang Z, Wang S, Zhao J, Yu C, Hu Y, Tu Y, et al. Naringenin ameliorates renovascular hypertensive renal damage by normalizing the balance of reninangiotensin system components in rats. Int J Med Sci. (2019) 16:644-53. doi: 10.7150/ijms.31075

101. Cheng L, Zheng W, Li M, Huang J, Bao S, Xu Q, et al. Citrus fruits are rich in flavonoids for immunoregulation and potential targeting ACE2. Preprints. (2020):doi: 10.20944/preprints202002.0313.v1

102. Imai Y, Kuba K, Rao S, Huan Y, Guo F, Guan B, et al. Angiotensin-converting enzyme 2 protects from severe acute lung failure. Nature. (2005) 436:112-6. doi: $10.1038 /$ nature 03712

103. Diaz JH. Hypothesis: angiotensin-converting enzyme inhibitors and angiotensin receptor blockers may increase the risk of severe COVID-19. J Travel Med. (2020) 27:1-2. doi: 10.1093/jtm/taaa041

104. Gattinoni L, Coppola S, Cressoni M, Busana M, Chiumello D. Covid-19 does not lead to a "Typical" acute respiratory distress syndrome. Am J Respir Crit Care Med. (2020) 201:1299-300. doi: 10.1164/rccm.202003-0817LE

105. Chousterman BG, Swirski FK, Weber GF. Cytokine storm and sepsis disease pathogenesis. Semin Immunopathol. (2017) 39:517-28. doi: 10.1007/s00281017-0639-8

106. Ye Q, Wang B, Mao J. Cytokine storm in COVID-19 and treatment. J Infect. (2020) 80:607-13. doi: 10.1016/j.jinf.2020.03.037

107. Zhang JJ, Dong X, Cao YY, Yuan YD, Yang YB, Yan YQ, et al. Clinical characteristics of 140 patients infected with SARS-CoV-2 in Wuhan, China. Allergy Eur J Allergy Clin Immunol. (2020) 75:1730-41. doi: 10.1111/all. 14238

108. Chen G, Wu D, Guo W, Cao Y, Huang D, Wang H, et al. Clinical and immunologic features in severe and moderate forms of Coronavirus disease 2019. medRxiv[Preprint]. (2020). doi: 10.1101/2020.02.16.2002 3903

109. Mu L, Hu G, Liu J, Chen Y, Cui W, Qiao L. Protective effects of naringenin in a rat model of sepsis-triggered acute kidney injury via activation of antioxidant enzymes and reduction in urinary angiotensinogen. Med Sci Monit. (2019) 25:5986-91. doi: 10.12659/MSM.916400

110. Romaszko E, Marzec-Wróblewska U, Badura A, Buciński A. Does consumption of red grapefruit juice alter naringenin concentrations in milk produced by breastfeeding mothers? PLoS One. (2017) 12:e0185954. doi: 10.1371/journal.pone.0185954

111. Breinholt VM, Svendsen GW, Dragsted LO, Hossaini A. The citrus-derived flavonoid naringenin exerts uterotrophic effects in female mice at human relevant doses. Basic Clin Pharmacol Toxicol. (2008) 94:30-6. doi: 10.1111/ j.1742-7843.2004.pto_940106.x

112. Kanaze FI, Bounartzi MI, Georgarakis M, Niopas I. Pharmacokinetics of the citrus flavanone aglycones hesperetin and naringenin after single oral administration in human subjects. Eur J Clin Nutr. (2007) 61:472-7. doi: 10.1038/sj.ejcn.1602543

113. Habauzit V, Verny MA, Milenkovic D, Barber-Chamoux N, Mazur A, Dubray $\mathrm{C}$, et al. Flavanones protect from arterial stiffness in postmenopausal women consuming grapefruit juice for $6 \mathrm{mo}$ : a randomized, controlled, crossover trial. Am J Clin Nutr. (2015) 102:66-74. doi: 10.3945/ajcn.114.104646

114. Nielsen ILF, Chee WSS, Poulsen L, Offord-Cavin E, Rasmussen SE, Frederiksen $\mathrm{H}$, et al. Bioavailability is improved by enzymatic modification 
of the citrus flavonoid hesperidin in humans: a randomized, doubleblind, crossover trial. J Nutr. (2006) 136:404-8. doi: 10.1093/jn/136. 2.404

115. Wang Y, Wang S, Firempong CK, Zhang H, Wang M, Zhang Y, et al. Enhanced solubility and bioavailability of naringenin via liposomal nanoformulation: preparation and in vitro and in vivo evaluations. AAPS PharmSciTech. (2017) 18:586-94. doi: 10.1208/s12249-016-0537-8

116. Kumar RP, Abraham A. PVP- coated naringenin nanoparticles for biomedical applications - in vivo toxicological evaluations. Chem Biol Interact. (2016) 257:110-8. doi: 10.1016/j.cbi.2016.07.012

117. Khan AW, Kotta S, Ansari SH, Sharma RK, Ali J. Self-nanoemulsifying drug delivery system (SNEDDS) of the poorly water-soluble grapefruit flavonoid Naringenin: design, characterization, in vitro and in vivo evaluation. Drug Deliv. (2015) 22:552-61. doi: 10.3109/10717544.2013.878003

118. Gera S, Talluri S, Rangaraj N, Sampathi S. Formulation and Evaluation of Naringenin Nanosuspensions for Bioavailability Enhancement. AAPS PharmSciTech. (2017) 18:3151-62. doi: 10.1208/s12249-017-0790-5

119. Lu WJ, Ferlito V, Xu C, Flockhart DA, Caccamese S. Enantiomers of naringenin as pleiotropic, stereoselective inhibitors of cytochrome P450 isoforms. Chirality. (2011) 23:891-6. doi: 10.1002/chir.21005
120. Bourian M, Runkel M, Krisp A, Tegtmeier M, Freudenstein J, Legrum W. Naringenin and interindividual variability in interaction of coumarin with grapefruit juice. Exp. Toxicol. Pathol. (1999) 51:289-93. doi: 10.1016/S09402993(99)80008-6

121. Fuhr U, Kummert AL. The fate of naringin in humans: a key to grapefruit juice-drug interactions? Clin Pharmacol Ther. (1995) 58:365-73. doi: 10. 1016/0009-9236(95)90048-9

Conflict of Interest: The authors declare that the research was conducted in the absence of any commercial or financial relationships that could be construed as a potential conflict of interest.

Copyright (c) 2020 Alberca, Teixeira, Beserra, de Oliveira, Andrade, Pietrobon and Sato. This is an open-access article distributed under the terms of the Creative Commons Attribution License (CC BY). The use, distribution or reproduction in other forums is permitted, provided the original author(s) and the copyright owner(s) are credited and that the original publication in this journal is cited, in accordance with accepted academic practice. No use, distribution or reproduction is permitted which does not comply with these terms. 